Etikonomi

Volume 15 (2), October 2015

P-ISSN: 1412-8969; E-ISSN: 2461-0771

Page 139 - 156

\title{
ANALYSIS OF ABDI KERTA RAHARDJA UNION HEALTH ASSESMENT
}

\author{
Indo Yama Nasarudin \\ UIN Syarif Hidayatullah Jakarta \\ yamaindo@gmail.com
}

\begin{abstract}
.
This study aims to identify and analyse the health assessment union of Abdi Kerta Raharja. Health assessment used measurement and calculation in Rule Deputy Control of Ministry of Union and SMEs of the Republic of Indonesia Number 6 Year 2016. Aspects for health assessment consists the capital aspect, productive asset quality aspects, management aspects, aspects of efficiency, liquidity aspect, the aspect of self-reliance and growth and aspects of the identity of union. Based on the results obtained value for all aspects of health assessment union of Abdi Raharja Kertais 81.00. It can be concluded that the union of Abdi Kerta Raharja have a healthy category for health assessment.
\end{abstract}

Keywords: health assessment; capital; productive asset quality; management; efficiency; liquidity

\begin{abstract}
Abstrak.
Penelitian ini bertujuan untuk mengidentifikasi dan menganalisis penilaian kesehatan koperasiAbdi Kerta Raharja. Penilaian kesehatan menggunakan pengukuran dan perhitungan dalam Peraturan Deputi Pengendalian Kementerian Koperasi dan UKM Republik Indonesia Nomor 6 Tahun 2016. Aspek untuk penilaian kesehatan terdiri aspek permodalan, aspek kualitas productice aset, aspek manajemen, aspek efisiensi, aspek likuiditas, aspek kemandirian dan pertumbuhan dan aspek identitas koperasi. Berdasarkan hasil yang diperoleh nilai semua aspek penilaian kesehatan koperasi Abdi Raharja Kerta adalah 81.00. Dapat disimpulkan bahwa koperasi Abdi Kerta Raharja memiliki kategori sehat untuk penilaian kesehatan.
\end{abstract}

Kata Kunci: penilaian kesehatan; permodalan; kualitas aktiva produktif; manajemen; efisiensi; likuiditas

First Draft: May 30, 2016; Revised: September 2, 2016; Approved: September 20, 2016 
Analysis of Abdi Kerta Rahardja Union Health Assesment

Indo Yama Nasarudin

\section{INTRODUCTION}

Union According to the Law of the Republic of Indonesia No.25 of 1992 is a business entity consisting of a person or legal entity with the bases union activities based on the principle of union as well as people's economic movement based on the principle of kinship where their main purpose union in Indonesia is for the welfare of members. According to ILO (International Labour Organization) union/union: an association of persons usually of limited means, who have voluntarily joined together to achieve a common economic end through the formation of democratically controlled business organization, making equitable contribution to the capital required and accepting a fair share of the risk and benefits of the undertaking.

According to Law no. 25 of 1992 concerning union article 4, the function and role of union are as follows: first build and develop economic capacity of society in general and members in particular to improve the economic and social welfare. Both, participating actively in efforts will enhance the quality of human life and society. The fourth seeks to realize and develop the national economy is a collective effort based on the principle of kinship and economic democracy.

According to the Regulation of the Minister of Union and SMEs (2009) "Health Union and unit savings and loan union is a union whose condition or circumstances are otherwise healthy, reasonably healthy, less healthy, unhealthy and very unhealthy". The aspect that is used for assessment of health union among others is capital, asset quality, management, efficiency, liquidity, independence and growth, and the identity of union". Rating of the union savings and credit union and unit is very beneficial to provide a picture of the condition of the union itself to the parties concerned, especially for union members and managers. In addition, the rating of the union is also done so that the union can evaluate and find out some problems in the implementation of its business.

Regulation of the Minister is later revealed to be more specific in Regulation Supervision Deputy Ministry of Union and SMEs number 6 in 2016 by dividing the soundness of the union into the category of healthy, healthy enough, in and under special supervision. 
Based on the assessment of the level of health in the regulation of Deputies, the authors assess the union of Abdi Kerta Rahardja. Union of Abdi Kerta Rahardjais a union with legal aspect number of 866/ BH / Meneg.I / X / 2009 dated October 26, 2009, located in the district of Tangerang, Banten Province. The union was chosen because of its contribution was good enough for inclusion and participation of unions in the economic empowerment as well as having excellent financial performance.

\section{METHOD}

This research is descriptive research and evaluative. Descriptive research is research conducted to determine the value of an independent variable, either a variable or more without making comparisons or linking to other variables. Evaluative research is commonly referred to as a data collection activities, or information, to be compared with the criteria, and then conclude. The gap or discrepancy the real condition of the object is to be evaluated with the expectation that the conditions stated in the criteria that is sought. The gap obtained a description of the object under study whether it is appropriate, less appropriate, or do not fit the criteria. This research was conducted in union Abdi Kerta Harja located PWS AN Block 31 Plot 19-20 Kadu village Tigaraksa Tangerang District Court District of Banten Province.

The object of research includes capital asset, asset quality, management, efficiency, liquidity, independence and growth, the identity of union in 2015. Furthermore, the subject of this study is the Board. In assessing the health of union, then to the aspects that given the weight of votes in accordance with the magnitude of the calculation results of the union appropriate weighting scores and grades based on Regulation of Control Deputy of Ministry of Union and SMEs number 6 in years of 2016. Rate the level of health is done by used the values expressed in numbers from 0 to 100 . 
Analysis of Abdi Kerta Rahardja Union Health Assesment

Indo Yama Nasarudin

\section{DISCUSSION}

Capital Aspect

Capital is a means or provision for doing business. Capital is a financial aspect that holds role important in an enterprise, including a union. A healthy of capital level union will show how quality level of that union. Capital aspect ratio assessed include equity capital to total assets, the ratio of equity capital to loans granted are at risk, and the capital adequacy ratio itself. The ratio of equity capital to total assets is intended to measure the ability of capital remain union in supporting the funding of the total assets. The measurement is done by comparing the equity by total assets. Categories optimal ratio of equity capital to total assets is 40 percent to 60 percent. The result of the calculation of the ratio of equity capital to total assets at the union of Abdi Kerta Rahardja can be seen in Table 1.

Table 1. Value of Capital Aspect for Union of Abdi Kerta Raharja

\begin{tabular}{llllll}
\hline No & Name of Ratios & Ratio & Value* $^{*}$ & Weight \% * & Score \\
\hline 1 & Equity to Total Assets Ratio & $31,01 \%$ & 50 & 6 & 3 \\
2 & $\begin{array}{l}\text { Equity to Loans that given risk } \\
\text { Ratio }\end{array}$ & $40,19 \%$ & 50 & 6 & 3 \\
$3 \quad \quad$ Capital Adequacy Ratio & $73,93 \%$ & 100 & 3 & 3 \\
Score & & & & $\mathbf{9}$ \\
Assesment Category & Health Enough & & \\
\hline
\end{tabular}

Source: processed data, The value and weight according to Regulations of Deputy

Control for Minsitry of union and SME number 6 year of 2016

According to the table 1, information obtained value of ratio of equity to total assets of $31.01 \%$. This ratio indicates that the situation is not too high. Value ratio was good and included in the healthy category is of $41 \%$ to $60 \%$. Thus Union of Abdi Kerta Rahardja should strive to raise additional equity from either principal or compulsory savings through the addition of new members or by increasing reserves of net income.

The ratio of equity capital against risky loans given that it is intended to measure the ability of their own capital to cover the risk of lending that are not backed by collateral. The measurement is done by comparing the own capital with loans granted are at risk. Categories optimal ratio of equity capital to loans 
given risk is equal to 100 percent or more. The higher this ratio is the better value that indicates the ability of unions to cover the risks of lending. The result of the calculation of equity to loans that granted risky ratio for union of Abdi Kerta Rahardja based on table 3.1 yield at $40.19 \%$. This indicates that the equity to loans that granted risky ratio are good enough but not too high so that the necessary efforts to increase the capacity of their equity.

The capital adequacy ratio itself is meant to measure the quality of capital weighted in favor of their risk-weighted assets (RWA) owned. The measurement is done by comparing the weighted capital (WC) to risk weighted assets (RWA). The result of the calculation of capital adequacy ratio itself in union of Abdi Kerta Rahardja can be seen in Table 3.1 to the ratio value of 73.9 percent. This indicates that the value of their own capital adequacy ratio in Abdi Kerta Rahardjahas been very good.

Based on the value of the capital aspect ratio, it can be stated that the value of health for capital aspect is generally quite healthy. Ratio of equity to total assets is good enough and need to be improved. Equity to loans that granted risky ratio was good enough but still needs to be improved. Capital adequacy ratio is very good so it needs to be maintained.

Productive Assets Quality Aspect

The quality of earning assets shows how much the effectiveness of the union in managing its resources. Aspects assessed the quality of earning assets include volume ratio of loans to members of the volume of loans granted, the risk ratio of NPL to loans, the ratio of risk reserves against the risk of bad loans, and the ratio of loans at risk of loans. The following table 2 presents information aspect ratios in productive asset quality.

The ratio of the volume of loans to members of the volume of loans granted for the purpose of measuring the activity of savings and loan unions to their members. The measurement is done by comparing the volume of loans granted to members of the volume of loans granted by the union as a whole. The result of the calculation of the volume of loans to members of the volume of loans granted ratio in Abdi Kerta Rahardja can be seen in Table 3.2 in the amount of 91.79 percent. The higher the ratio of the volume of loans to members of the 
volume of loans granted showed the better union in managing the quality of its productive assets. Category optimum volume ratio of loans to members of the volume of loans granted is greater than $75 \%$. Thus the ratio of the volume of loans is to members of the volume of loans granted in the union of Abdi Kerta Rahardja very good.

Risk of NPLs to loans granted ratio intended to measure the risk of troubled loans of all loans granted. The measurement is done by comparing the troubled loans to loans granted by the union. The smaller the ratio of nonperforming loans to loans risk loans, the higher the value of the credit or the quality is getting better. That is, the better the quality of loans. Categories optimal risk ratio of NPL to loans is $0 \%$.

The result of the calculation of risk NPL to loans granted ratio in the Union Abdi Kerta Rahardja can be seen in Table 3.2 to the value ratio of $8.86 \%$. This shows that the risk ratio of NPL to loans granted in the union of Abdi Kerta Rahardja quite low but still need to be lowered. Categories optimal risk ratio of NPL to loans is $0 \%$.

Table 2. Value of Productive Assets Quality Aspects

Union of Abdi Kerta Raharja

\begin{tabular}{llllll}
\hline No & Name of Ratios & Ratio & Value* & Weight \%* & Score \\
\hline 1 & $\begin{array}{l}\text { Loans volume to members to } \\
\text { the volume of loans granted }\end{array}$ & 100 & 10 & 10 \\
$\begin{array}{l}\text { ratio. } \\
2\end{array}$ & $\begin{array}{l}\text { Loan Risk to loan of granted } \\
\text { ratio }\end{array}$ & $8,86 \%$ & 80 & 5 & 4 \\
3 & $\begin{array}{l}\text { Risk reserves to troubled Loans } \\
\text { ratio }\end{array}$ & 10 & 5 & 0,5 \\
4 & $\begin{array}{l}\text { Risk loans to loan of granted } \\
\text { ratio }\end{array}$ & $1,82 \%$ & 5 & 5 \\
\hline
\end{tabular}

Score

Assesment Category

Health

Source: processed data,The value and weight according to Regulations of Deputy

Control for Minsitry of union and SME number 6 year of 2016

The ratio of risk reserves against the risk of a bad loan is intended to measure the quality of risk reserves in addressing the risk of troubled loans. The 
measurement is done by compared the risk reserve with a bad loan risk. The smaller the ratio of risk reserves against the risk of bad loans is not good then the credit value. Categories optimal ratio Risk Reserves against Delinquent Loans is greater than $90 \%$ to $100 \%$. The result of the calculation of risk reserve ratio against the risk of bad loans in the Union Abdi Kerta Rahardja can be seen in Table 3.2 amounted to $2.48 \%$. This ratio indicates a low capacity that needs to be cautious in extending financing.

The ratio of loan risk for loans granted intended to measure the level of loans at risk in a given year. The measurement is done by compared the loan risk with the loans. Categories optimal ratio of loans at risk of loans is less than $21 \%$. The result of the calculation of the ratio of loans at risk of loans granted in the Union of Abdi Kerta Rahardja can be seen in table 3.2 by $1.82 \%$. It shows a very good condition because it is far below the $21 \%$ of the category of the good.

Thus that from the productive assets quality aspect of in the Union of Abdi Kerta Rahardja the general level of health aspects productive asset quality is healthy. Loan volume ratio on a Member of the volume of loans granted has been very good so it need to be maintained. Risk ratios Loans to Loans Delinquent low that need to be maintained the principle of all caution in lending. The risks to the Reserve Ratio Troubled loans low so need to be cautious in lending. Ratio The ratio of loans at risk of Loans low that need to be maintained the principle of all caution in lending.

Management Aspects

Management is a system that is divided into planning, organizing, actuating, and controlling is done to achieve the goals that have been determined using human and other resources. Management aspects rated by 5 components. Component in question is a component of general management, institutional management, capital management, asset management and liquidity management. General management intended to measure the ability of unions to manage USP. In assessing general management component uses scored system on each "yes". There are 12 questions included in the list of general management components. Each "yes" of the 12 questions rated 0.25 . The results of 
calculations and general management component score Union Abdi Kerta Rahardja can be seen in Table 3.3 to the value of 3 which is the maximum score. This shows that the union aspects of general management Abdi Kerta Rahardja own good.

Institutional management are intended to measure the ability of unions to manage human resources and union work system. In assessing these institutional management components using a score system in each "yes".There are 6 list of questions included in institutional management components. Each "yes" answer the question of 6 rated 0.5. The results of the calculations and scoring on a union institutional management component Abdi Kerta Rahardja by Table 3 with a value of 3 . This indicates that the management component Abdi Kerta Rahardja union institution has been very good.

Tabel 3. Measurement and Scored of Union Management Aspect

\begin{tabular}{lccc}
\hline Component & Sum of Answer “yes" (a) & Value (b) & Score(a)*(b) \\
& & & \\
\hline General & 12 & 0,25 & 3 \\
Institution & 6 & 0,5 & 3 \\
Capital & 5 & 0,6 & 3 \\
Assets & 10 & 0,3 & 3 \\
Liquidity & 5 & 0,6 & 3 \\
Score & & Health & $\mathbf{1 5}$ \\
Assesment Category & & & \\
\hline
\end{tabular}

Source: data processed

Capital management is intended to measure the ability of unions to manage their own capital. In assessing capital management component uses a scoring system for each "yes" answer. There are 5 list of questions included in capital management component. Each "yes" answer the questions of 5 rated 0.6. The results of the calculations and scoring component of capital management in the union Abdi Kerta Rahardja by Table 3.3 with a value of 3 . This indicates that the management component Abdi Kerta Rahardja union institution has been very good.

Asset management is intended to measure the ability of unions to manage loans (crediting) of property owned. In assessing the asset management component uses a scoring system for each "yes" answer. There is a list of 10 
questions included in the asset management component. Each "yes" of the 10 questions rated 0.3. The results of the measurement and scored component of capital management in the union Abdi Kerta Rahardja is showed in table 3 with a value of 3 . This indicates that the management component Abdi Kerta Rahardjaunion institution has been very good.

Liquidity management is intended to measure the ability of unions to meet its short term obligations. In assessing the liquidity management components used a scoring system on each "yes". There are 5 list of questions included in liquidity management components. Each "yes" answer the questions of 5 rated 0.6. The results of the measurement and scored component of capital management in the union Abdi Kerta Rahardja is showedin table 3 with a value of 3. This indicates that the management component Abdi Kerta Rahardja union institution has been very good.

The general views of the management aspect of general management of Abdi Kerta Rahardja Union have very good administrators and managers to maintain the general management of the union. Management of union institutions is already excellent administrators and managers to maintain the institutional management of the union. Union capital management has been very good administrators and managers to maintain the union capital management. Asset management has been very good union administrators and managers to maintain the asset management of the union. Liquidity management has been very good union administrators and managers to maintain the liquidity management of the union.

Efficiency Aspects

Assessment of efficiency for union showed how much union is able to provide efficient services to its members based on the use of its existing assets. Aspects of the rated efficiency ratio of operating expenses include services to the gross participation, the ratio of operating expenses to gross residual net income, and service efficiency ratios.

The ratio of operating expenses to gross enrolment services is intended to measure the ability to provide efficient services to its members on the use of asset owned. Measurements were performed by comparing the operating 
expenses with the participation of members of the gross. The lower the ratio of operating expenses to gross enrolment services is better value of efficiency aspects of the union. Category optimum ratio of operating expenses to gross enrolment services is less than $90 \%$. The result of the calculation of operating cost ratio of services to gross participation in union Abdi Kerta Rahardja according to table 4 by $88.71 \%$ below the value of $90 \%$. Thus the value of operating cost ratio of services to gross participation in union Abdi Kerta Rahardja has been very good.

Table 4. Value of efficiency Aspect for Union of Abdi Kerta Rahardja

\begin{tabular}{|c|c|c|c|c|c|}
\hline No & Name of Ratios & Ratio & Value* & Weight \%* & Score \\
\hline 1 & $\begin{array}{l}\text { Operational service cost to } \\
\text { gross particiaptions ratio }\end{array}$ & $88,71 \%$ & 100 & 4 & 4 \\
\hline 2 & $\begin{array}{l}\text { Operating cost to gross residual } \\
\text { net income }\end{array}$ & $77,29 \%$ & 50 & 4 & 2 \\
\hline 3 & Sercive efficiency ratio & $31,76 \%$ & 0 & 2 & 0 \\
\hline \multicolumn{2}{|c|}{ Score } & & & & 6 \\
\hline \multicolumn{2}{|c|}{ Category } & \multicolumn{3}{|c|}{ Health Enough } & \\
\hline
\end{tabular}

Source: processed data,The value and weight according to Regulations of Deputy Control for Minsitry of union and SME number 6 year of 2016

The ratio of operating expenses to gross residual of net income is intended to measure the level of profitability of the funds used residual of net income. The measurement done by compared the operating expenses to gross residual of net income. The lower the value of the ratio of operating expenses to residual of net income Gross show better efficiency aspects of union values. Category optimum ratio of operating expenses to gross residual of net income is less than or equal to $40 \%$. The results of calculation of the ratio of operating expenses to gross residual of net income in union Abdi Kerta Rahardja according to table 4 of $77.29 \%$ is greater than $40 \%$. The value of the ratio of operating expenses to gross residual of net income union Abdi Kerta Rahardja is relatively good. However, much work is needed to lower business costs or increase the value of income of the union. 
The efficiency ratio of service is intended to measure the level of employee service to its customers. The measurement is done by comparing the cost of the employee with the volume of loans. The lower ratio value between the cost of the employee and the volume of loans showed better efficiency aspects of union values. Categories optimal service efficiency ratio is less than $5 \%$. The result of the calculation of the efficiency ratio in the union service Abdi Kerta Rahardja according to table 4 by $31.76 \%$ is greater than $5 \%$. The value of the efficiency ratio in the union service Abdi Kerta Rahardja is relatively poor. So that efforts need to lower the cost of employees or increasing the loan value the union members.

Thus the general views of the management aspect Abdi Kerta Raharja Union is that the ratio of operating expenses to gross participation is very good so it is necessary to maintain efficiency by lowering operating costs or increase the gross enrolment services. The ratio of operating expenses to the gross residual of net income is quite good but still needs to make improvements by lowering business costs or an increase in the residual of net income. The efficiency ratio is not good so services need to improve efficiency by reducing staff costs.

Liquidity Aspects

The liquidity ratio of union used to measure the level of liquidity union in meeting short-term obligations. Aspects assessed liquidity includes cash and bank ratios against current liabilities and the ratio of loans granted to the funds received.

The ratio of cash and bank to current liabilities intended to measure the ability of unions to meet its short term obligations. The measurement done by compared the cash and bank by current liabilities. Categories optimal ratio of cash and banks against current liabilities is $10 \%$ to $15 \%$. The result of the calculation of the ratio of cash and banks against current liabilities of the Abdi Kerta Rahardja union is according to table 5 of $12.52 \%$ under optimal category. Thus the optimal value ratio and the ratio of cash to current liabilities of banks in the union Abdi Kerta Rahardja has been very good. 
Tabel 5. Value of Liquidity Aspect for Union of Abdi Kerta Rahardja

\begin{tabular}{lllllll}
\hline No & Name of Ratios & & Ratio & Value* $^{*}$ & Weight \% * & Score \\
\hline $1 \quad \begin{array}{l}\text { Cash and Bank to current } \\
\text { liabilities ratio }\end{array}$ & $12,52 \%$ & 100 & 10 & 10 \\
$\begin{array}{l}\text { Loans granted to fund received } \\
\text { ratio }\end{array}$ & $79,71 \%$ & 75 & 5 & 3,75 \\
$\begin{array}{l}\text { Score } \\
\text { Category }\end{array}$ & & & & $\mathbf{1 3 , 7 5}$ \\
\hline
\end{tabular}

Source: processed data, The value and weight according to Regulations of Deputy Control for Minsitry of union and SME number 6 year of 2016

The ratio of loans to the funds received measure levels of troubled loans. The measurement done by compared the loans with funds received. The higher the ratio of loans to the funds received shows the ratio the better. Categories optimal ratio of loans to the funds received are $80 \%$ to $90 \%$ more. The results of calculations of loans against the funds received in the union Abdi Kerta Rahardja according to table 5 of $79.71 \%$ are under the optimal category. Thus the value of the ratio of loans to the funds received in the union Abdi Kerta Rahardja relatively well.

Thus the general views of the management aspect Abdi Kerta Raharja Union is that the ratio of cash and bank the need to maintain a good current liabilities and bank cash portion and liabilities lancer. Loans to the funds received from either needs to maintain a portion of the loans and the funds received.

Independence and Growth Aspects

Independence and the growth show how far the union can generate profit and independent in the subject of capital. Aspects of self-reliance and growth of unions were assessed among other assets profitability ratios, equity profitability ratio and operational independence. Assets profitability ratio is intended to measure the ability of unions to earn income or capital gains from the assets or managed. The measurement done by compared the residual of net income before tax to total assets. 
The higher the value of the assets profitability ratio indicates better independence and growth of unions. Categories optimal asset profitability ratio is $10 \%$ or more. The result of the calculation of the profitability ratio of assets to Abdi Kerta Rahardja union is according to table 6 of $3.51 \%$ are under the optimal category. This the value of the assets profitability ratio in the union Abdi Kerta Rahardjais still not good.

Tabel 6. Value of Independence and Growth for

Union of Abdi Kerta Rahardja

\begin{tabular}{llllll}
\hline No & Name of Ratios & Ratio & Value* $^{*}$ & Weight \% * & Score \\
\hline 1 & Asset profitability ratio & $3,51 \%$ & 25 & 3 & 0,75 \\
2 & Equity profitability ratio & $11,32 \%$ & 100 & 3 & 3 \\
3 & $\begin{array}{l}\text { Operational independence } \\
\text { and service ratio }\end{array}$ & $117,49 \%$ & 100 & 4 & 4 \\
$\begin{array}{l}\text { Score } \\
\text { Category }\end{array}$ & Health & & & $\mathbf{7 , 7 5}$ \\
\hline
\end{tabular}

Source: processed data,

Equity profitability ratio measures the ability of its own capital to generate residual of net income. The measurement done by compared the total residual of net income section member with their equity. The higher the value of equity profitability ratio indicates better independence and growth of unions. Categories optimal equity profitability ratio is $5 \%$ or more. The result of the calculation of the profitability ratio of equity capital to the union Abdi Kerta Rahardja according to table 6 is $11.32 \%$ that above the optimal category. Thus the value of the equity profitability ratio to the union Abdi Kerta Rahardja has been very good.

The ratio of operational independence and services is to measure independence in operational service for members. The measurement done by compared the net participation by unions operating expenses plus load. Categories optimal operational independence ratio is over $100 \%$. The result of the calculation of the ratio of self-reliance and service operations in the union of Abdi Kerta Rahardja according to table 3.6 of $117.49 \%$ is above the optimal category. Thus the ratio of the value of self-reliance and service operations in the union Abdi Kerta Rahardja has been very good. 
Thus the general views of the management aspect for union of Abdi Kerta Raharja that asset profitability ratio is less good shows that the portion of the residual of net income before tax is still very low compared to the total assets. The profitability ratio of capital itself very well shows that the portion of the residual of net income before taxes compared with their own capital is very supportive. Excellent operational independence ratio shows that the share of net enrolment compared with operating expenses and burden on unions strongly support

Identity Union Aspect

Assessment of the identity of unions for the purpose of assessment with regard to how much union can achieve its goal of promoting its members. Aspects of the identity of unions are assessed include the gross enrolment ratio and the ratio of economic promotion member. Gross enrolment ratio is intended to measure the ability of unions to enable its members about the savings and loan. The measurement done by compared the gross enrolment coupled with the participation of the gross revenue. Gross enrolment ratio is higher / large percentage the better. Categories optimal gross enrolment ratio is $75 \%$ or greater. The result of the calculation of gross enrolment ratio in the union Abdi Kerta Rahardja according to table 6 of $99.50 \%$ is above the optimal category. Thus the value of the gross enrolment ratio in the union Abdi Kerta Rahardja has been very good.

Table 7. Value of Identity Aspect of Abdi Kerta Rahardja Union

\begin{tabular}{llllll}
\hline No & Jenis Rasio & Rasio & Nilai* $^{*}$ & Bobot \% $^{*}$ & Skor \\
\hline 1 & Gross participation ratio & $99,50 \%$ & 25 & 3 & 7 \\
2 & $\begin{array}{l}\text { Member of economic promotion } \\
\text { ratio }\end{array}$ & $10,49 \%$ & 100 & 3 & 3 \\
$\begin{array}{l}\text { Score } \\
\text { Category }\end{array}$ & & & 10 \\
\hline
\end{tabular}

Source: processed data, 
Tabel 8. The Result of Health Assesment for Abdi Kerta Rahardja Union

\begin{tabular}{|c|c|c|c|c|c|}
\hline NO & HEALTH ASSESMENT ASPECT & RATIO & SCORE & VALUE & CATEGORY \\
\hline A & CAPITAL & & & 9.00 & $\begin{array}{l}\text { HEALTH } \\
\text { ENOUGH }\end{array}$ \\
\hline 1 & Equity to Total Assets Ratio & $\begin{array}{l}31.01 \\
\%\end{array}$ & 3.00 & & \\
\hline 2 & Equity to Risk Loans Granted Ratio & $\begin{array}{l}40.19 \\
\%\end{array}$ & 3.00 & & \\
\hline 3 & $\begin{array}{l}\text { Capital Adequacy Ratio to Weighted } \\
\text { Assets by Risk Ratio }\end{array}$ & $\begin{array}{l}73.93 \\
\%\end{array}$ & 3.00 & & \\
\hline $\mathbf{B}$ & PRODUCTIVE ASSETS QUALITY & & & 19.50 & HEALTH \\
\hline 1 & $\begin{array}{l}\text { Volume of Loans for Members to } \\
\text { Volume of Loans Granted Ratio }\end{array}$ & $\begin{array}{l}91.79 \\
\%\end{array}$ & 10.00 & & \\
\hline 2 & $\begin{array}{l}\text { Trouble loans risk to loans granted } \\
\text { ratio }\end{array}$ & $8.86 \%$ & 4.00 & & \\
\hline 3 & Risk reverse to trouble loan risk ratio & $2.48 \%$ & 0.50 & & \\
\hline 4 & Risk loans to loans granted ratio & $1.82 \%$ & 5.00 & & \\
\hline $\mathbf{C}$ & MANAGEMENT & & & 15.00 & HEALTH \\
\hline 1 & General Management & 3.00 & 3.00 & & \\
\hline 2 & Institutional Management & 3.00 & 3.00 & & \\
\hline 3 & Capital Management & 3.00 & 3.00 & & \\
\hline 4 & Assets Management & 3.00 & 3.00 & & \\
\hline 5 & Liquidity Management & 3.00 & 3.00 & & \\
\hline D & EFICIENCY & & & 6.00 & $\begin{array}{l}\text { HEALTH } \\
\text { ENOUGH }\end{array}$ \\
\hline 1 & $\begin{array}{l}\text { Operational service cost to gross } \\
\text { participations ratio }\end{array}$ & $88.71 \%$ & 4.00 & & \\
\hline 2 & $\begin{array}{l}\text { Operating cost to gross residual net } \\
\text { income }\end{array}$ & $77.29 \%$ & 2.00 & & \\
\hline 3 & Service efficiency ratio & $31.76 \%$ & - & & \\
\hline $\mathbf{E}$ & LIQUIDITY & & & 13.75 & HEALTH \\
\hline 1 & $\begin{array}{l}\text { Cash and Bank to current liabilities } \\
\text { ratio }\end{array}$ & $12.52 \%$ & 10.00 & & \\
\hline 2 & Loans granted to fund received ratio & $79.71 \%$ & 3.75 & & \\
\hline $\mathbf{F}$ & INDEPENDENCE AND GROWTH & & & 7.75 & HEALTH \\
\hline 1 & Asset profitability ratio & $3.51 \%$ & 0.75 & & \\
\hline 2 & Equity profitability ratio & $11.32 \%$ & 3.00 & & \\
\hline 3 & $\begin{array}{l}\text { Operational independence and service } \\
\text { ratio }\end{array}$ & $\begin{array}{l}117.49 \\
\%\end{array}$ & 4.00 & & \\
\hline G & IDENTITY UNION & & & 10.00 & HEALTH \\
\hline 1 & Gross participation ratio & $99.50 \%$ & 7.00 & & \\
\hline \multirow[t]{3}{*}{2} & Member of economic promotion ratio & $10.49 \%$ & 3.00 & & \\
\hline & SCOORE ASSESMENT & 81,00 & & & \\
\hline & WHOLE CATEGORY & HEALTH & & & \\
\hline
\end{tabular}

Source: data processed 
The ratio measures the ability of members of the economic promotion of unions in providing benefits and costs of participation of unions through the principal savings and mandatory savings. The measurement done by compared the economic promotion members with principal plus mandatory savings deposits. The ratio of members of the higher economic promotion / large percentage is the better. Categories optimal gross enrolment ratio is $10 \%$ or greater. The results of calculation of the ratio of economic promotion of the union members Abdi Kerta Rahardja according to table 3.6 of $10.49 \%$ is above the optimal category. Thus the value of the ratio of economic promotion of the union members Abdi Kerta Rahardja has been very good.

Thus the general view of the management aspect Abdi Kerta Raharja Union is that the gross enrolment ratio is very good so preserving the value of gross enrolment and revenue is needed. Member economic promotion ratio is very good so maintaining economic promotion member is needed.

\section{CONCLUSION}

According to analysis and discussed we can conclude that union of Abdi Kerta Rahardja has equity to total Assets ratio good enough and need to be improved. Ratio of equity to loans granted risk good enough but still needs to be improved. Capital adequacy ratio very good so it needs to be maintained. Loan volume ratio on a Member of the volume of loans granted has been very good so it need to be maintained. Risk Loans to Loans Delinquent low that need to be maintained the principle of all caution in lending. The risks to the reserve ratio troubled loans low so need to be cautious in lending. The ratio of loans at risk of loans low that need to be maintained the principle of all caution in lending.

General Management cooperation has been very good administrators and managers to maintain the general management of the cooperation. Institutional management has been very good administrators and managers to maintain the institutional management of the cooperation. Capital Management has been very good administrators and managers to maintain capital management. Asset Management has been very good administrators and managers to maintain the 
asset management of the cooperation. Liquidity management has been very good administrators and managers to maintain the liquidity management of the cooperation.

The ratio of operating expenses to gross participation is very good so it is necessary to maintain efficiency by lowering operating costs or increase the gross enrolment services. The ratio of operating expenses to the residual of net income is quite good but still needs to make improvements by lowering business costs or an increase in the residual of net income. The efficiency ratio is not good so services need to improve efficiency by reducing staff costs.

The ratio of cash and current liabilities of banks against either need to maintain cash portion and bank as well as current liabilities. Loans to the funds received from either needs to maintain a portion of the loans and the funds received.

Unfavourable asset profitability ratio shows that the portion of the residual of net income before tax is still very low compared to the total assets. Excellent profitability ratio of equity shows that the portion of the residual of net income before taxes compared with their own capital is very supportive. Excellent operational independence ratio shows that the share of net enrolment compared with operating expenses and burden on union is very supportive.

Gross enrolment ratio is very good so preserving the value of gross enrolment and revenue is needed. Member economic promotion ratio is very good so maintaining economic promotion member is needed.

\section{REFERENCES}

Baswir, R. 2000. Koperasi Indonesia. Edisi Pertama. Yogyakarta: BPFE. Fahmi, R. (2011). Analisis Kinerja Keuangan. Bandung: Alfabeta.

Gitosudarmo, I.\& M. Najmudin. (2003). Anggaran Perusahaan. Yogyakarta: BPFE. Jumingan. (2005). Analisis Laporan Keuangan. Jakarta: PT Bumi Aksara. Margaretha, F. (2011). Manajemen Keuangan Untuk Non Keuangan. Jakarta: Erlangga. 
Analysis of Abdi Kerta Rahardja Union Health Assesment

Indo Yama Nasarudin

Peraturan Menteri Negara Koperasi dan Usaha Kecil dan Menengah Republik Indonesia No. 14/Per/M.KUKM/XII/2009.

Rudianto. (2010.) Akuntansi Koperasi. Edisi Kedua. Jakarta: Erlangga.

Sitio, A.\&H. Tamba. (2001). Koperasi Teori dan Praktik. Jakarta: Erlangga.

Srihartini, I. (2009). Penilaiann Kinerja Koperasi Pegawai Republik Indonesia (KPRI) "BANGUN" di Kecamatan Wonosari periode Tahun 2005-2008. (Unpublished Thesis). Yogyakarta: Universitas Negeri Yogyakarta.

Subandi. (2009). Ekonomi Koperasi (Teori dan Praktik). Bandung: Alfabeta.

Triwibowo, A. (2012). Analisis Kinerja Keuangan Koperasi Pegawai Republik Indonesia “Mapan Sejahtera” UNY Periode Tahun 2009-2011. (Unpublished Thesis). Yogyakarta: Universitas Negeri Yogyakarta. 